\title{
Preliminary investigations on the Ichthyodiversity of Kilifi Creek, Kenya
}

\author{
Dalmas Oyugi \\ IUCN-EARO, P.O. Box 68200 Nairobi, Kenya
}

Key words: ichthyodiveristy, hill's indices, Kilifi creek

\begin{abstract}
In order to determine fish spatial variation, the Kilifi Creek was divided into three sampling zones: entrance, middle zone, and Creek end. Sampling was by both gill and cast nets. Hill's diversity indices were used as a measure of spatial diversity variance. A total of 95 species from 45 families were recorded. Gerres filamentosus, Pomadasys multimaculatum, Leiognathus equula, and Terapon theraps occurred commonly. Highest species richness $\left(\mathrm{N}_{\mathrm{o}}=\right.$ $68)$ and diversity $\left(N_{1}=31.09\right)$ was recorded at the entrance and Creek middle respectively. Most of the species overlap with the highest overlap index $(L=2.52)$ recorded between Cynoglossus gilchristi and Scombroides lysan. The creek's ichthyodiversity show considerable variability, with the high richness at the entrance attributed to the presence of open water visitor species. The high number of species compares well to records from Gazi Bay and Mida Creek with some species not found further south.
\end{abstract}

\section{INTRODUCTION}

Like many other tropical systems, the ichthyodiversity of eastern Africa is remarkably high, almost comparable to the archipelagos of South East Asia. It is one of the top three global diversity hotspots (McAllister et al., 1994, from Gell and Whittington, 2002). To a large extent, this is due to heterogeneous and productive systems of mangroves, seagrass beds, coral reefs, sand and mudflats besides the open pelagic systems, which occur in the region (Harling, 1980; Valentine and Heck, 1999; Gell and Whittington, 2002). McClanahan (1997) remarks that $85 \%$ of fish catches in East Africa comes from the inshore habitats.

That new discoveries are still being made in the icthyofauna of the region is shown by the recent report of a coelocanth Latimeria chalumnae (Smith, 1939) off the Kenyan coast at Malindi only $50 \mathrm{~km}$ north of the Kilifi study site (De Vos and
Oyugi, 2002), two specimens found at Kilwa, Tanzania (Benno pers comm.) and 21 specimens from Tanga region (Verheij pers comm). Previously this species was reported from Grand Comore Island, south of Madagascar, the Mozambique Channel and in Indonesia.

Ichthyodiversity in the Western Indian Ocean (WIO) can significantly vary between habitats. Gell and Whittington (2002) report that ichthyodiversity in Quirimba (northern Mozambique) varies significantly among pure seagrass beds to coral reefs and mangroves allies. De Troch et al. (1996) report three distinct communities, river fed creek, upstream and the bay proper, in Gazi Bay (about $70 \mathrm{Kms}$ south of Kilifi Creek). Bock (1972; 1975) reports on several differences in species distribution and densities between shallow lagoons and creeks in Kenya. Smith and Heemstra (1986) show how the reefs in East Africa share common fish species despite their geomorphological differences (i.e. from fringing reefs to rock islands - atolls). 
Ever-increasing human pressure leads to habitat degradation: pollution, overfishing, nonselective harvesting of mangroves, besides climate change critically threatens the general diversity of marine and coastal fauna and flora. There is an urgent need to determine the current ichthyodiversity of the region for comparison with historical data in order to develop conservation strategies. While such work has been done in Gazi Bay (De Troch et al., 1996; Wakwabi, 1999) and in Mida Creek (Mwatha and Olembo, 1998) little is known of Kilifi Creek.

\section{MATERIALS AND METHODS}

\section{Sampling Sites}

Kilifi Creek is about $50 \mathrm{~km}$ north of Mombasa, Kenya's main coastal city. During high tide, the Creek extends $15 \mathrm{~km}$ inland with a depth ranging from $0 \mathrm{~m}$ at the Creek end to $15 \mathrm{~m}$ at the mouth, during the lowest low water. For sampling, the Creek was divided into three zones: a) the entrance, later named Kitsoka, which is characterized by heavy waves from the open sea, b) the middle zone, later named Musimuni, has a hotel to the east and a Yacht club to the west and c) the Creek end, later named Kibokoni, is characterized by narrower mangrove creeks and shallow waters and extends to the northwest, where small streams such as Rare River enter. At low tides most of this zone becomes exposed making boat sampling almost impossible. Each of the zones were further subdivided into 3 subsections (Fig. 1).

\section{Sampling methods}

A small motor vessel was used to access the three zones, but for fish sampling a small dugout canoe locally known as Dau was used to set out and haul nets. Sampling was carried out during the southeast monsoon. Gillnets, castnets and handnets were used in sampling. Gillnets measured $20 \mathrm{~m}$ long with mesh size ranging from $5-10 \mathrm{~cm}$. were set along the edge of the Creek, and across the Creek in the middle region. Handnets were used to sample cryptic species such as gobies and blennids in isolated intertidal pools at low tide. Nine samples were taken at each sampling site during the day at high tide. Identification and nomenclature follows Smith and Heemstra (1986) and Van Der Elst (1993).

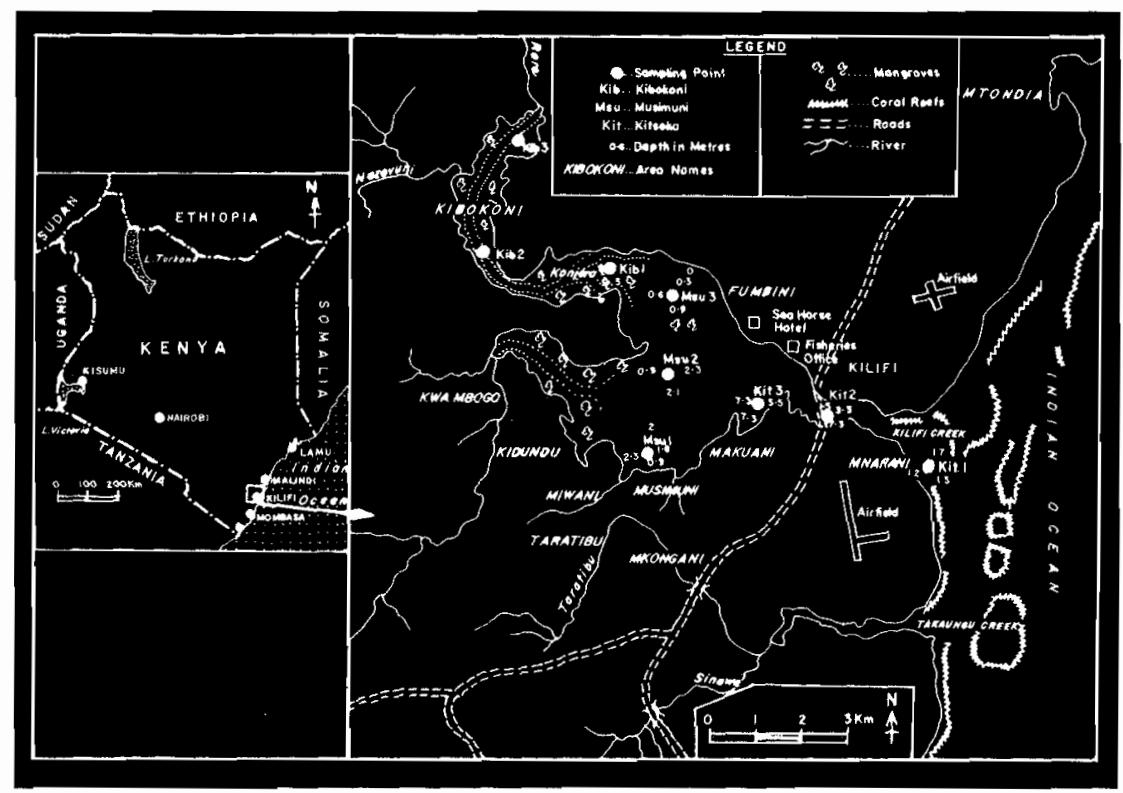

Fig. 1. A map of Kilifi Creek showing sampling stations 


\section{Fish diversity}

Hill's diversity indices (1973): $N_{d}, N_{l}, N_{2}$ and $N_{\infty}$ estimated site diversity as follows;

$N_{o}$ : diversity as the average number of species per habitat.

$N_{I}$ : diversity as the exponent of Shannon

Wiener diversity index given as;

$N_{1}=\exp \left(-\sum p_{i}\left(\ln p_{i}\right)\right)$

$p i=n i / N$

where: $p i$ : is the proportional abundance of $i^{\text {th }}$ species,

$n i$ : number of individuals of $\mathrm{i}^{\text {th }}$ species,

$N$ : total number of individuals

$N_{2}$ : species evenness index as a reciprocal of Simpson's dominance Index;

$N_{2}=1 / \Sigma p_{i}^{2}$

$N+\infty$ : species dominance index based on

the reciprocal of the proportional abundance of the commonest species;

$N_{+\infty}=1 /$ proportional abundance of the commonest species

(iii).

\section{Habitat overlap}

To establish how different species share different habitats, a parameter referred to as habitat overlap index (L) was calculated as;

$$
\mathrm{L}=(A / X Y) \Sigma\left(x_{i} y_{i} / a_{i}\right)
$$

Where: $x i=$ number of species 1 in the habitat $i$

$y i=$ number of species 2 in the habitat $i$

ai $=$ availability of habitat $i$

$\mathrm{A}=$ the sum of habitat availabilities

$\mathrm{X}=$ total population of species 1

$\mathrm{Y}=$ total population of species 2 (Hulbert, 1978, from Abrams, 1980)

\section{RESULTS}

A total of 95 species belonging to 45 families were recorded from 306 specimens sampled from the Creek. The total list of species and their zonal distribution in the Creek is given in Table 1. Threadfin pursemouth Gerres filamentosus Cuvier, 1829, cock grunter Pomadasys multimaculatum (Playfair,1866), Slimy Leiognathus equula (Forskål 1775), and straight-lined thorn fish
Terapon theraps (Cuvier, 1829) are widely distributed and commonly found in all the three zones of the Creek.

Kitsoka had the highest species richness $\left(\mathrm{N}_{\mathrm{o}}\right)$ of 68 followed by Musimuni 29 and Kibokoni 18 . The same trend was followed by species diversity $\left(\mathrm{N}_{1}\right)$, where Kitsoka had 31.09, Musimuni 19.39 and Kibokoni 9.07. However, Musimuni had the highest species evenness $\left(\mathrm{N}_{2}\right)$ and dominance $\left(\mathrm{N}_{\infty}\right)$ of 14.29 and 7.36 respectively followed by Kitsoka 11.44 and 3.71, and Kibokoni 5.43 and 2.9 (Fig. 2). Figures 3 and 4 show positive correlation between species evenness and dominance, and between species richness and diversity respectively.

Most of the fish species overlap in the three broader zones of the Creek with the highest overlap index (L) occurring between ripple fin tongue Cynoglossus gilchristi (Ogilby, 1910) and double spotted queenfish Scombroides lysan (2.42); frogtail goby Oxyurichthys papuensis (Valensciennes, 1837) and toothed soapy Gazza minuta (Bloch, 1797) (2.19) and thornfish Terapon jarbua (Forskål, 1775) and O. papuensis (2.06). On the other hand, the weakest overlap was recorded between yellowbanded goatfish Upeneus vittatus (Forskål, 1775) and C. gilchristi (0.11), S. lysan and $U$. vittatus $(0.15)$, and $O$. papuensis and giant kingfish Caranx ignobilis (0.19) (Table 2).

\section{DISCUSSION}

Fish diversity in the Western Indian Ocean is relatively high and generally both species richness and diversity are higher than in temperate and subtropical bays, and estuaries, where as few as six species may contribute $70 \%$ of the total catch (Quinn, 1980, Little et al., 1988). The preliminary assessment of Kilifi Creek shows this where the most abundant eight families contributed only 66 $\%$ of the total catch.

Fish communities are also different from one habitat to another as shown by Gell and Whittington (2002) from the Quirimba Archipelago in northern Mozambique. This is also seen in Kilifi Creek. The entrance to the Creek has a higher species richness than the landward stations, due to the presence of numerous oceanic fish. This was also observed by McClanahan and 


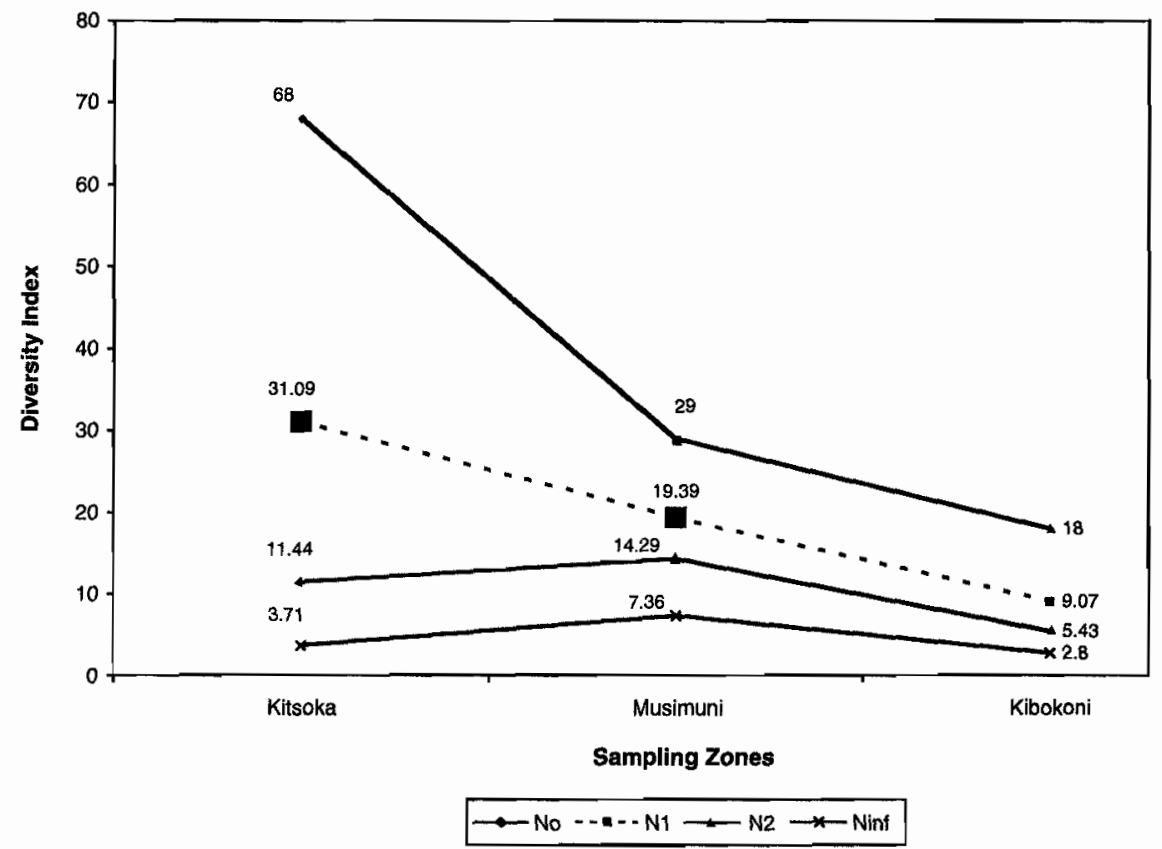

Fig. 2. Hill's diversity Indices of Ichthyofauna in Kilifi Creek

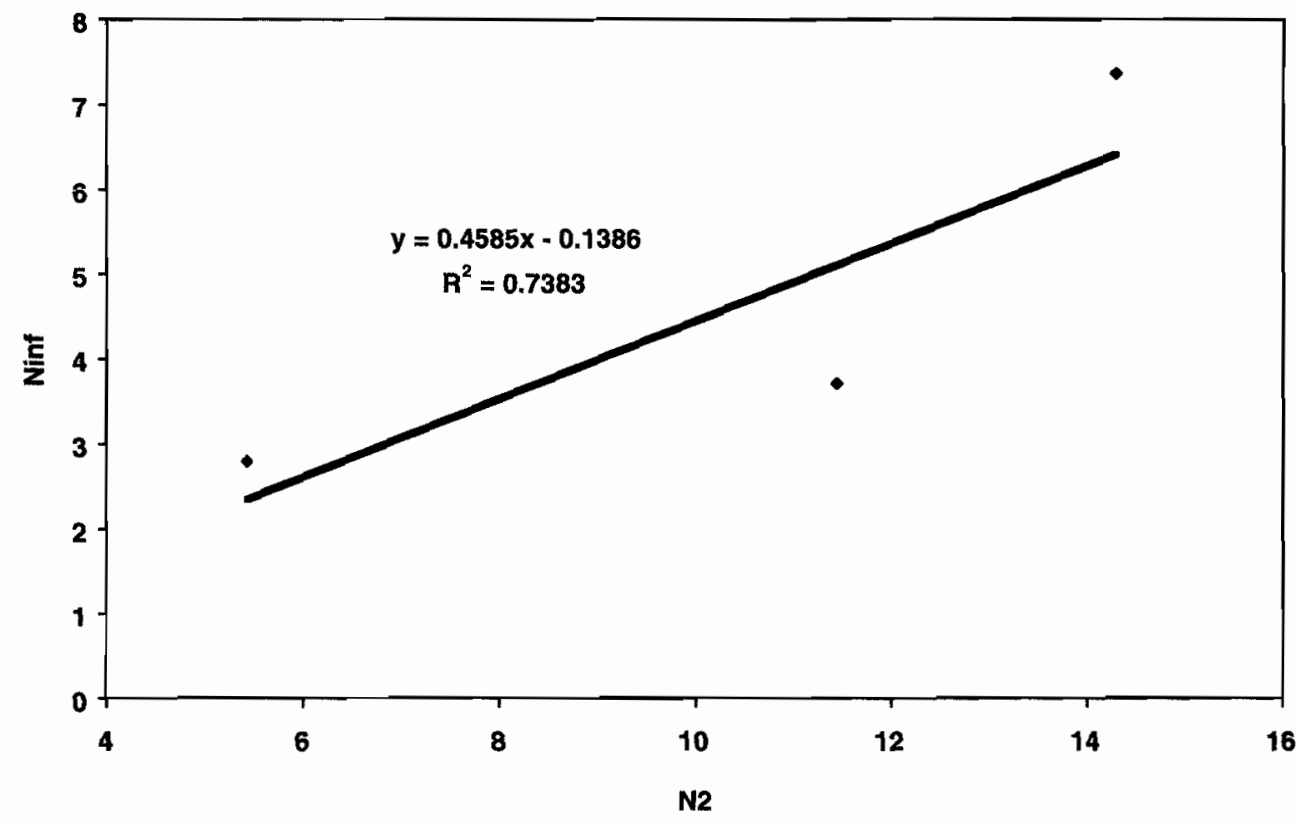

Fig. 3. Relationship between species evenness (N2) and dominance (Ninf) in Kilifi Creek 


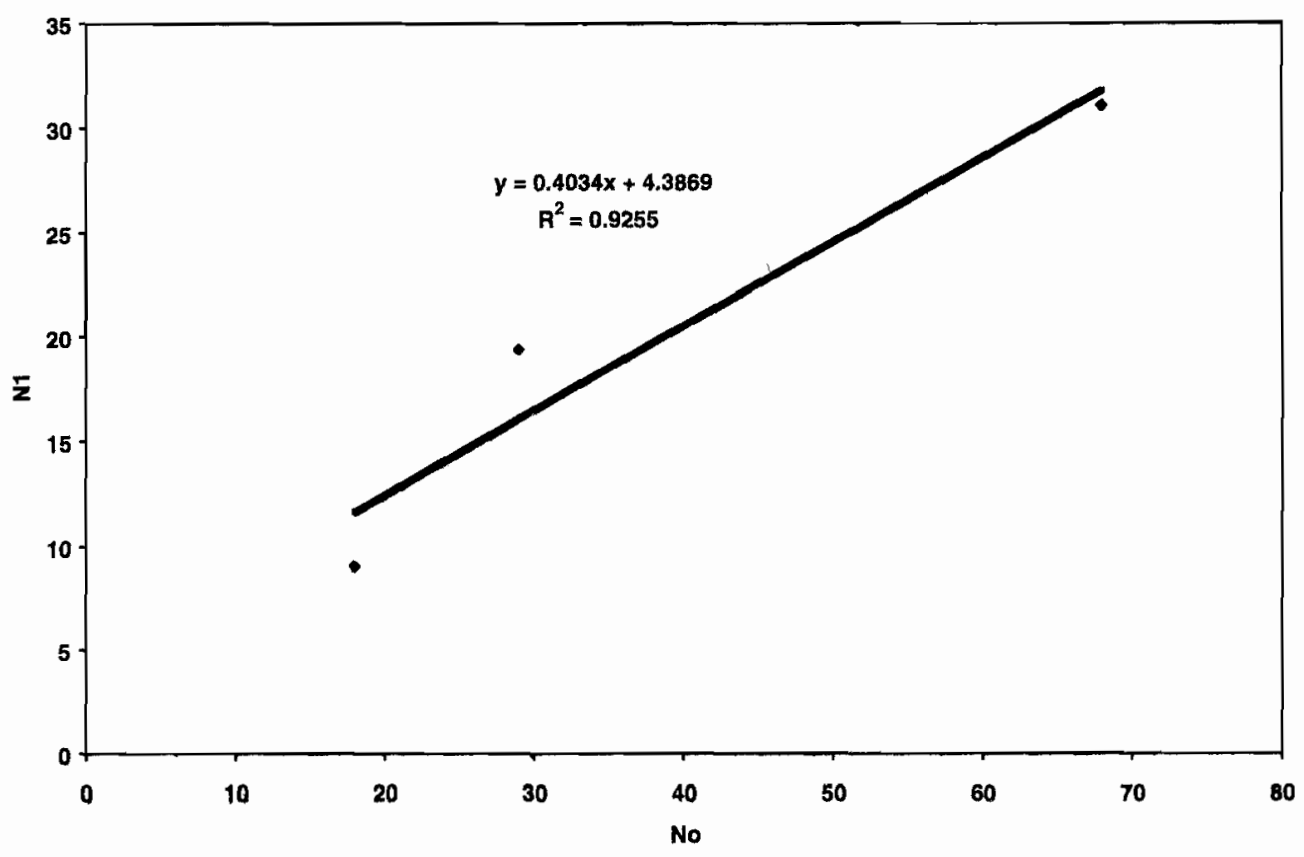

Fig. 4. Relationship between species richness (No) and diversity (N1) in Kilifi Creek

Mangi (2000), who also noted that species evenness at local level ( $\alpha$ diversity) in Kenya, including but not limited to angelfishes, does not relate to the entire WIO. Some visitors such as the queenfish Scombroides lysan, $S$. tol, $S$. commersonnianus, and Carongoides caerueopinnatus hardly enter the main Creek, except when tidally driven. However, the Creek's species richness compares to that of Mida Creek (Mwatha and Olembo, 1998), to the north and Gazi Bay (De Troch et al. 1996; Wakwabi, 1999), to the southern part of Kenya. The latter recorded 75 fish species from 40 families in Gazi Bay, against the 96 species from 45 families recorded from the Creek. Ninety five percent of their catches were, however, juveniles and this does not allow an exact comparison with the Kilifi records, since some of the adult fishes are highly migratory. Our sampling time was limiting the accuracy of presence absence records for comparative purposes.

At family level, the Kilifi ichthyodiversity resembles the Quirimba diveristy as reported by Gell and Whittington (2002), but differs at the species level. In Mozambique for example the endemic blackfoot cardinal Apogon mozambiquensis was not found yet was recorded from Kilifi Creek. At the same time, the commonly caught haemulids in Kilifi Creek ( $P$. commersonni, $P$. kaakan, $P$. multimaculatum) were not recorded from their intensive sampling of the seagrass and the coral reefs of the Quirimba. The relatively high number of families (45) from only 306 individuals compared to 58 families recorded by Gell and Whittington (2002) from 46, 629 individuals in Quirimba is striking.

Little et al. (1988) recorded 86 species belonging to 43 families from Tudor Creek (Mombasa) using a beach seine which were dominated by families Gobiidae, Gerridae, while Signathidae and Leiognathidae dominated the Kilifi Creek samples. However, due to the differences in sampling methods, including the predominant use of gillnets, many of the smaller fish such as gobies, mudskippers and blennids may have escaped capture. In his preliminary checklist by underwater survey, Bock (1975) reports a general lack of Serraninidae, Gobiidae and Blennidae from Kitsoka area of Kilifi Creek. The few blennids and gobies mentioned in the current list were caught by orthodox methods including 
Table 1. Record of fishes of Kilifi Creek in three different zones

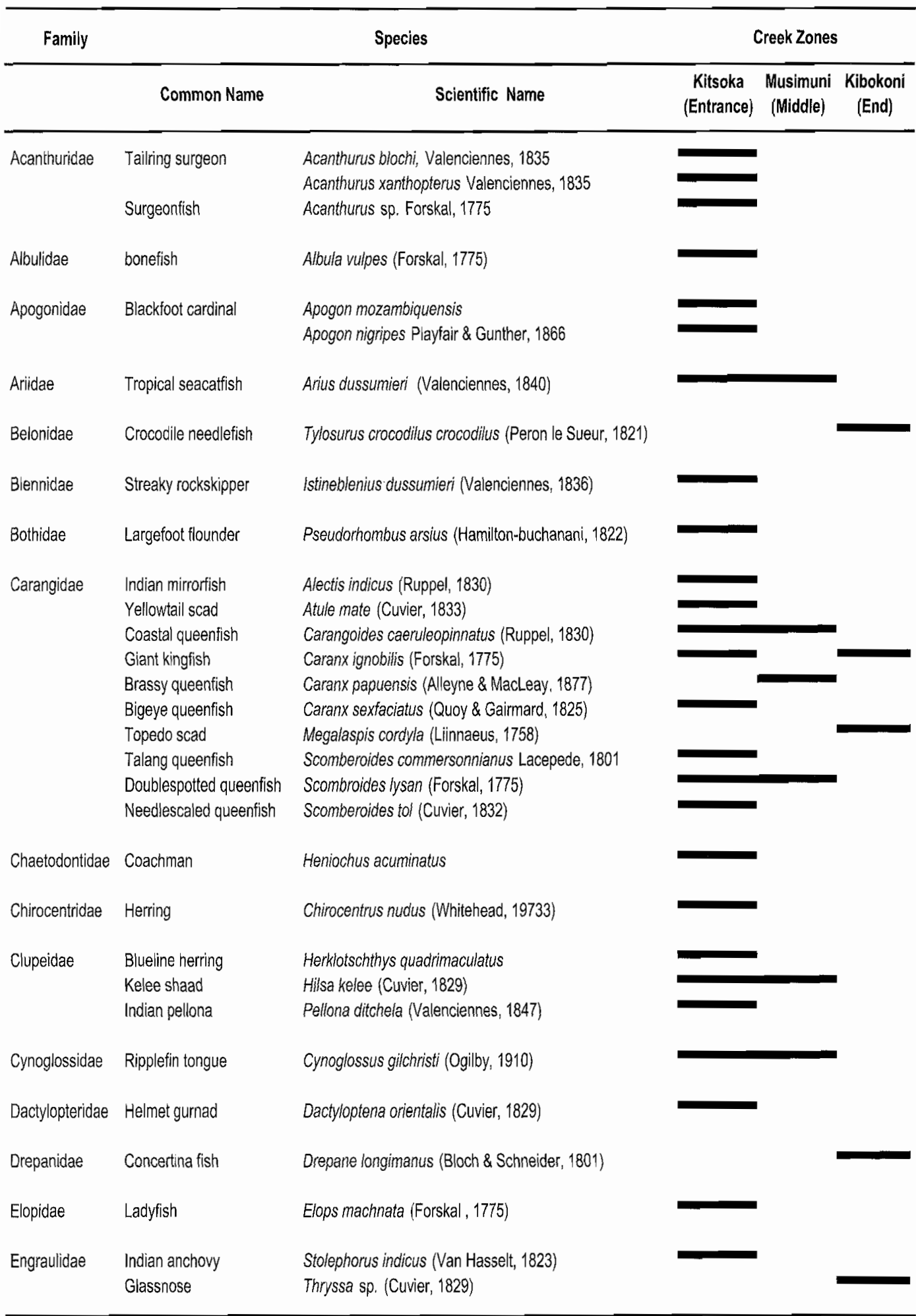


Table 1. (Contd)

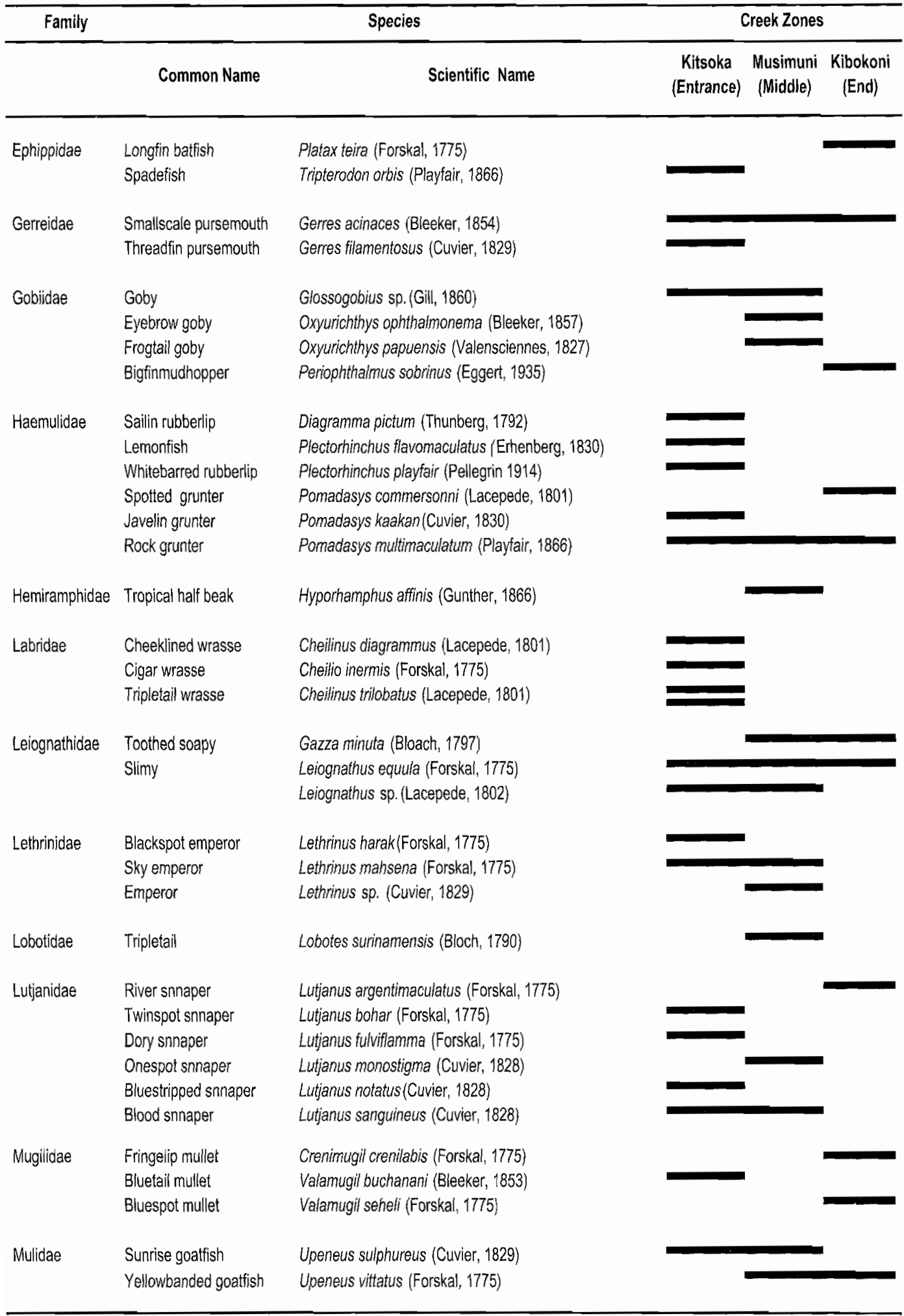


Table 1. (Contd)

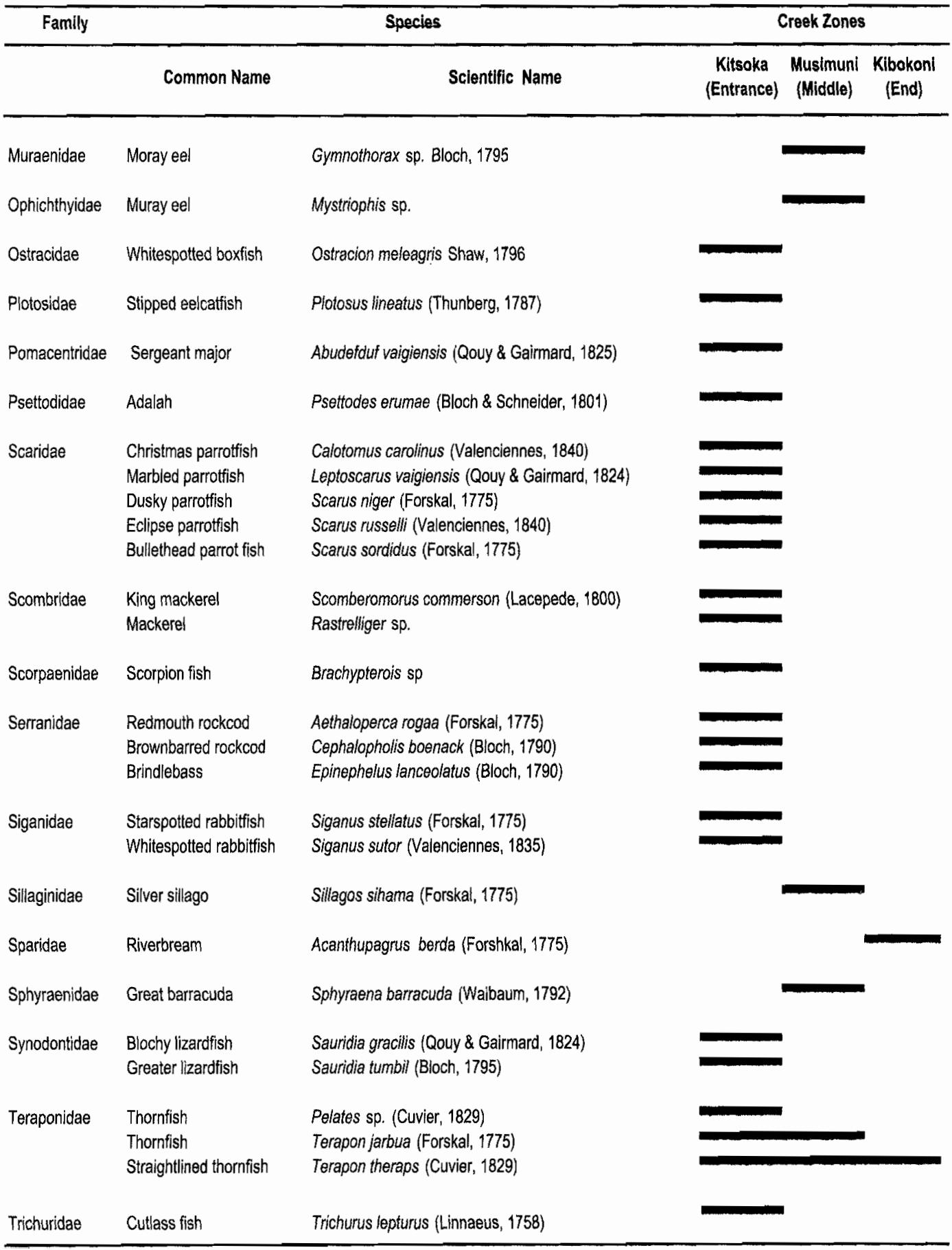




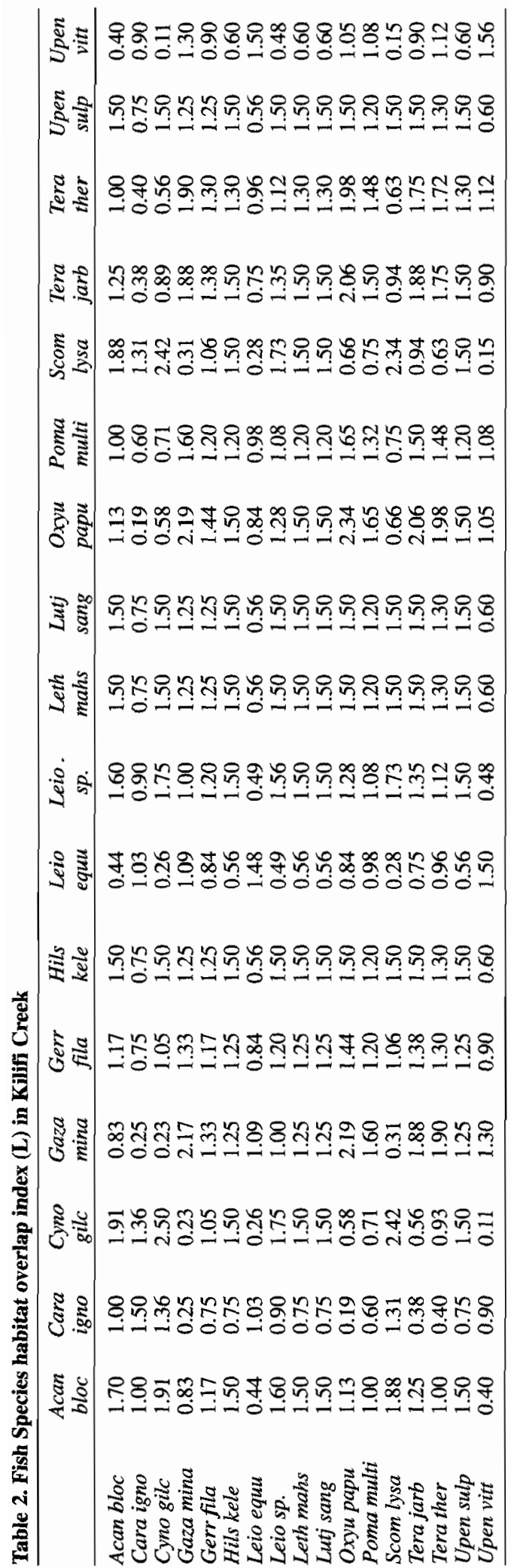

irregular use of hand-nets besides literally hitting them (particularly the mudskippers) with objects.

According to Richmond (1997), the biogeography of the WIO is fairly uniform, with a wide spread of many flora and fauna. This could partly explain the general similarity of most of the fish communities in the entire coast. At localised levels, a number of fish species exhibited niche overlap, but a comprehensive study on their feeding habits is needed to explain such coexistence.

At a wider spatial scale, this short survey revealed three species, which have not previously been recorded in the southern Western Indian Ocean based on the selection included in Smith and Heemstra (1986). They include the wolfherring Chirocentrus nudus - which is easily confused with C. dorab (occurring in the Southern WIO), scorpionfish Brachypterios sp. and thornfish Pelates sp. As opposed to the C. dorab, C. nudus has a longer pectoral fin, which is equal to the distance from gill opening to mid snout. The Pelates sp. recorded from the Creek lacks a dark mark behind the head as is found in its close relative $P$. quadrimculatum in southern Africa. The Kilifi thornfish has only two horizontal bands along its body. The Brachypterios sp. recorded from Kilifi has a relatively shorter spine about equal to the soft rays and the dorsal spines are less than half the body depth. This species is close to the $B$. serrulatus (Richardson, 1846) recorded from the Gulf of Oman (Smith and Heemstra, 1986). Detailed taxonomic studies would establish the status of the two species in the Creek.

\section{CONCLUSIONS}

The ichthyodiversity of Kilifi Creek is relatively high compared to other areas along the Kenyan coast. The short survey revealed a total of 95 species belonging to 45 families with considerable variability in local diversity variability between the creek end and its mouth. A more comprehensive survey, covering a whole lunar cycle would map out the exact status of the fish diversity of the creek to enable conclusive comparison with other regions and to facilitate identification of conservation and management strategies. Such a study would further establish the status of some of the species, which 
were recorded from the Creek, which do not appear in Smith and Heemstra (1986) and thus help establish the southern boundary for these species.

Acknowledgments-This work was made possible with funds from Rufford Small Grants of Whitley Laing Foundation. We would like to thank the management of National Museums of Kenya for providing us with a vehicle and related facilities. Our special thanks also go to Mr. J.K. Wanyoike, District Fisheries Officer Kilifi and his team, for hospitality and provision of a working base during the survey.

\section{REFERENCES}

Abrams, P. 1980. Some comments on measuring niche overlap. Ecology, 61(1): 44-49.

Bock, K.R. 1972. Preliminary checklist of lagoonal fishes of Diani, Kenya. Journal E.A. Nat. Hist. Soc. and Nat. Mus. No. 137.

Bock, K.R. 1975. Preliminary checklist of the fishes of the South Bank., Kilifi Creek, Kenya. Journal E.A. Nat. Hist. Soc. and Nat. Mus. No. 148.

De Troch, M., Mees, J. , Papadopoulos I. \& Wakwabi E.O. 1996. Fish communities in a tropical bay (Gazi Bay, Kenya): Seagrass beds Vs unvegetated areas. Netherlands Journal of Zoology, 46(3-4); 236-252.

De Vos, L. \& Oyugi D. O. 2002. First capture of a coelacanth, Latimeria chalumnae Smith, 1939 (Pisces: Latimeriidae), off Kenya. South Africa Journal of Marine. Science 98: 345- 347.

Gell, F. and Whittington M. W. 2002. Diversity of fishes in seagrass beds in the Quirimba Archipelago, Northern Mozambique. Journal of Marine and Freshwater Research, 53(2): 115-121.

Harling, M.M. (1980) Seagrass epiphytes. In: Phillips, R.C. and McRoy, C.P. (eds). Handbook of seagrass biology: An ecosystem perspective. Garland STPM Press, New York.

Hill, M.O. 1973. Diversity and evenness: a unifying notation and its consequences. Ecology, 54: 427432 .
Hulbert, S.L. 1978. The measurement of niche overlap and some relatives. Ecology, 59: 67-77.

Little, M. C., Reay, P. J. and Grove, S. J. 1988. The fish community of an East African mangrove creek. J. Fish Biol. 32: 729-747.

McAllister, D.E., Schueler F.W., Roberts C.M. \& Hawkins J.P. 1994. Mapping and GIS analysis of the global distribution of coral reefs on an equalgrid. In: Miller, R.I. (ed.) Mapping the Diversity of Nature, Chapman \& Hall, London.

McClanahan, T.R. 1997. Recover of fish populations from heavy fishing: does time heal all? Proc $8^{\text {th }}$ Coral Reef Symp, 2: 2033-2038.

McClanahan, T.R and Mangi, S. 2000. Spillover of exploitable fishes from a marine park and its effect on the adjacent fishery. Ecological Application, 10(6): 1792-1805.

Mwatha, G.K. and Olembo, B. 1998. The fishery of Mida Creek. In: Mwatha G.R., Fondo, E., Uku, J. and Kitheka, J.U. (eds) Mida Creek biodiversity project final technical report, the Netherlands Project.

Quinn, N.J. 1980. Analysis of temporal changes in fish assemblages in Serpentine Creek, Queensland. Env. Biol.Fishes 5: 117-133.

Richmond, M.D. (ed.). 1997. A guide to the seashores of eastern Africa and the Western Indian Ocean Islands. Sida Department for Research Cooperation, SAREC, $448 \mathrm{p}$.

Smith, M. and Heemstra, P.C. (eds). 1986. Smiths'Sea fishes, Macmillan South Africa (publishers) (Pty) LTD, Johannesburg, $1047 \mathrm{p}$.

Valentine, J.F. and Heck. K.L. 1999. Seagrass herbivory: evidence for the continued grazing of marine grasses. Marine Ecology Progress Series, 176: $291-302$

Van der Elst, R. 1993. A guide to the common sea fishes of Southern Africa. Struik Publishers, Cape Town, $398 \mathrm{p}$.

Wakwabi, E.O. 1999. The Ichthyofauna of a tropical mangrove bay (Gazi Bay, Kenya): community structure and trophic organization. PhD Thesis, University of Gent, Belgium $216 \mathrm{p}$. 